\title{
ANALYSIS OF INTEREST FACTORS FOR ENTREPRENEURSHIP OF ACCOUNTING EDUCATION STUDENTS
}

\author{
Noviyan Bhekti Pamungkas, Supri Wahyudi Utomo, \& Elana Era Yusdita \\ Accounting Education, Universitas PGRI Madiun, Madiun, Indonesia
}

\begin{abstract}
This study aims to determine the various factors that become the interest in entrepreneurship in accounting education students at Universitas PGRI Madiun. This study used a qualitative approach and the type of research was descriptive. The researcher conducted interviews with informants, namely accounting education students at the Universitas PGRI Madiun. The results of this study are that the informants R, Y, T, K, and P are interested in entrepreneurship, but the informant $(\mathrm{R})$ has an introverted personality. Then for the informant $(\mathrm{P})$, the poor learning achievement factor did not become an obstacle in him being interested in entrepreneurship, another uniqueness was found, namely that the informant $(\mathrm{K})$ did not have support from friends and had little leadership. For this reason, it is suggested to have leadership training, public speaking and entrepreneurship skills for students.
\end{abstract}

Keywords: social support; leadership in business; entrepreneurial skills; salesmanship; entrepreneurial theory

\section{INTRODUCTION}

Indonesia is the fourth most populous country in the world after China, India and the United States, with a projected 269,6 million people in 2020 according to estimates by the Central Statistics Agency (BPS, 2018). make good use of natural resources. However, with a large population, the government will face several problems, namely problems in the availability of educational facilities, food and clothing and most importantly the problem of providing employment opportunities for all Indonesian citizens.

According to the Ministry of Industry of the Republic of Indonesia (Anonymous, 2018) currently Indonesia needs around 4 million people to become new entrepreneurs to help boost economic structure. Due to the current

*Corresponding Author.

e-mail: noviyanbhekti14@gmail.com ratio of entrepreneurs in the country is still around $3.1 \%$ of the total population in Indonesia. Therefore, it is important to introduce and educate the Indonesian people about entrepreneurship.

According to Suyono (2019) currently Indonesia is facing problems regarding unemployment due to increasingly limited employment opportunities and more and more new graduates from higher education who are less able to compete with other graduates in finding employment and entrepreneurial interest in residents with tertiary education levels who are still lacking. According to data from the Central Statistics Agency (BPS, 2020) the total workforce in February 2020 was 137.91 million, an increase of 1.73 million compared to February 2019. However, the number of the workforce has increased, the Labor Force Participation 
Noviyan B.P., Supri W.U., \& Elana E.Y. / Analysis of Interest Factors for Entrepreneurship of Accounting Education Students / JEE, Vol. 9, No. 2, September 2020, pp 85-100

Rate (TPAK) decreased by 0.15 percentage points and in the past year, unemployment increased by 60 thousand people, in contrast to the Open Unemployment Rate (TPT) which fell to $4.99 \%$ in February 2020.

The increasing number of the workforce each year causes the unemployment rate to also increase due to competition in looking for work. This incident can occur due to the lack of interest of the Indonesian people in entrepreneurship. If the system of thinking of society is not renewed, what happens Indonesia will experience many problems, one of which is that Indonesia will continue to be a working nation. According to Franita (2016) Indonesia is a country with a large population, but a large population cannot guarantee having capable human resources. One of the causes of unemployment is the low level of a capable workforce. The habit of being lazy is also a result of the increasing number of unemployed people in Indonesia.

So that this does not happen, motivation, interest and knowledge in entrepreneurship must be increased. Because by choosing the pathway in the entrepreneurial sector, the number of unemployed figures in Indonesia can be reduced. In this case it is not only individual students who play a role, universities must also play a role by prioritizing the quality of their students in creating jobs, not prioritizing students to graduate quickly and get a job. Entrepreneurial interest must be instilled in each student so that after graduating students are able to create new jobs with their respective passions.

According to Adnyana \& Purnami (2016), the existence of entrepreneurship education so far has been an important factor in developing interest in entrepreneurship. Related to the existence of influential entrepreneurship educa- tion, awareness is needed about how to foster the creation of capable young entrepreneurs. Meanwhile, according to Saputri (2019), the factors that influence entrepreneurial interest in students are profit, freedom in work, fulfilment of personal dreams, and independence. Unlike Primandaru (2017) who found out 3 factors that become students' interest in entrepreneurship, namely internal locus of control, social support and need for achievement. Ayuningtias \& Ekawati (2015) examined the effect of independent variables, namely family environment, campus environment, personality and entrepreneurial motivation on the dependent variable, namely student interest in entrepreneurship. These four factors have almost the same influence in building an interest for students to become entrepreneurs. According to Praswati (2014), there are 8 factors that become students' interest in entrepreneurship, namely the desire to be a boss, innovation, leadership, flexibility, finance and the environment.

Previous research is a reference for researchers in conducting research so that it can enrich the theory used in reviewing the research carried out. However, the researcher wished to conduct research that was different from previous studies which mostly used quantitative methods, for this study researchers used qualitative methods. We can dig deeper into the answers using qualitative methods and allow for more reasons than just answering the Likert scale of quantitative methods. In addition, this kind of research has not been carried out by the Accounting Education at the Universitas PGRI Madiun.

Based on the background that has been described, this research is focused on finding out the various factors that become the interest in entrepreneurship in students of the Universitas PGRI Madiun. The results of this study are 
expected to be able to provide input for the development of an entrepreneurial education framework in higher education in encouraging the emergence of scholars who choose careers as entrepreneurs.

\section{METHOD}

The purpose of this study was to determine what factors are the reasons for students choosing entrepreneurial careers, so the research method used in this study is a qualitative research approach and the type of research is descriptive which allows the researcher to research under natural conditions (Sugiyono, 2016). This research was conducted by extracting data from informants regarding their interest in entrepreneurship from the interview process which must be answered by the informants.

The data from this study took from 5 accounting education students, especially in the 8th semester, who had taken entrepreneurship courses. The five students with the initials T, Y, $\mathrm{S}, \mathrm{K}$, and $\mathrm{R}$, they have different characters, family backgrounds and living environments. This can be determined by the researcher by interviewing about the character, family background and environment where the informant lives.

The interview is supported by using interview guidelines which include social support factors, leadership spirit, achievement, trading spirit, motivation, innovation, extroversion, profit, freedom of work and visionary interest in student entrepreneurship. The data analysis technique used the stages of data reduction, data presentation and data verification. The data validation technique used source triangulation on the answers issued by the 5 informants. The source triangulation technique was used to test the credibility of the data that was asked using the same questions to different sources (Sugiyono, 2016). Researchers in conducting their research will meet directly with informants at their respective homes or meet directly at the informant's location throughout May 2020.

\section{RESULTS}

This study uses data analysis techniques that are qualitative in nature, with data obtained from interviews and documentation compiled according to the facts in the field and forming a definition from the triangulated data. Here are the results:

\section{Social Support Factors}

The informant $(\mathrm{R})$ stated that he is interested in entrepreneurship and has the support of his parents, friends and the environment who work as entrepreneurs.

"Of course there is social support from family, friends and groups. Support from family, of course, comes from my father who is already involved in the world of entrepreneurship, the support of my friends, many of my friends who work in the field of entrepreneurship and my environment, many of whom are entrepreneurs."

The informant $(\mathrm{Y})$ stated that he is interested in entrepreneurship and there is support from family, friends and the environment by looking at business opportunities.

"Of course, there must be people from the environment as well as from my friends and family because I see from the environmental factors the business factors and the business opportunities. For example, seeing in today's era, in marriage, we have to need a lot of goods and equipment and also rent 
Noviyan B.P., Supri W.U., \& Elana E.Y. / Analysis of Interest Factors for Entrepreneurship of Accounting

Education Students / JEE, Vol. 9, No. 2, September 2020, pp 85-100

for weddings. Then besides that there is also support from my family because without support from my family, maybe I will not get support and support is very important for me to run this business."

The informant (T) stated that there was only support from family and friends in their interest in entrepreneurship.

"....Because maybe from parents, there must be support from friends, for example, from marketing, we also pass friends from parents, definitely support like that."

The informant $(\mathrm{K})$ only received support from the family in his interest in entrepreneurship.

"I think there is, because from my family environment, from my own parents it's like running a grocery store business. In my opinion, there is no influence from the circle of friends."

Then the informant $(\mathrm{P})$ received support from family and friends in his interest in entrepreneurship.

"Yes, I am interested because many of my friends are entrepreneurs and also the support from my parents."

\section{The Spirit of Leadership}

The informant (R) has a leadership spirit that can make his business even better.

"Of course there is, bro, because my leadership spirit will make my business even better.”

The informant $(\mathrm{Y})$ stated that the spirit of leadership emerged in himself because of his interest in leading his business.

"Of course I have a leadership spirit because entrepreneurship emerges from within myself, automatically with my entrepreneur- ship who has an idea and also leads in this business."

The informant $(\mathrm{T})$ stated that the spirit of leadership exists because of his desire to be boss in the sense that he does not want to be enslaved by others.

"I want to manage my own business because in myself I do not want to join people or be enslaved by these people. It is better for us to be leaders in our own business."

The informant $(\mathrm{K})$ only has a little leadership spirit but is interested in entrepreneurship and wants to be the boss.

"I think there is, but I have a little bit of leadership."

The informant $(\mathrm{P})$ stated that a man must have a leadership spirit.

"Yes, of course there is because a man must have a leadership spirit that is when he becomes entrepreneurial."

\section{Achievement Factor}

The informant $(\mathrm{R})$ stated that there was a correlation between learning achievement and entrepreneurship courses which would later be used as provisions for developing his business.

"There is a connection between courses and learning achievement that can become a provision for knowledge in which I will develop my business later."

The informant $(\mathrm{Y})$ stated that the value of entrepreneurship courses obtained was a learning achievement to remain interested in entrepreneurship.

"I am still interested in entrepreneurship because yesterday when I was in college, in the entrepreneurship course, thank God I got a B grade and because I was also inter- 
ested in that course and when I was practicing entrepreneurship I was also very interested in direct practice."

The informant $(\mathrm{T})$ stated that entrepreneurship knowledge has an impact on him later entrepreneurship.

"Yes, it is very influential, bro. Examples such as in our marketing management can be through social media or word of mouth or through other marketing mixes."

The informant $(\mathrm{K})$ stated that learning achievement is an additional value in later entrepreneurship.

"In terms of learning achievement and the value of entrepreneurship courses from myself, maybe there is an interest in me. It's like getting more knowledge."

The informant $(\mathrm{P})$ stated that the interest in entrepreneurship with learning achievement has no relation to being interested in entrepreneurship because even though the value is not good, the informant $(\mathrm{P})$ is still interested in entrepreneurship.

"Although my academic achievement scores and my entrepreneurship course scores are lacking, I am still interested in entrepreneurship.”

\section{Trade Spirit Factor}

The informant (R) stated that the spirit of commerce is important for the implementation of the business he will run.

"The problem is that if I can't trade, I won't be able to become an entrepreneur. The spirit of commerce is essential for putting my business in order to make it work."

The informant $(\mathrm{Y})$ stated that the spirit of commerce is a person's initial capital in entrepreneurship.
"Alhamdulillah, I also have a trading spirit because an entrepreneur's capital is trading whether it is offering services or products that will be offered to customers later."

The informant $(\mathrm{T})$ the spirit of commerce he got is a derivative of his family.

"Yes, I have a trading spirit, like I do this marketing, my family has passed down."

The informant $(\mathrm{K})$ stated that his trading spirit was obtained by upbringing from his parents since childhood.

"In my opinion, I already have a trading spirit, because from childhood I have helped my parents in trading."

The informant $(\mathrm{P})$ stated that the trading spirit he got came from experiences that were experienced related to buying and selling.

"Yes, because as entrepreneurs, if we don't have a trading spirit, we can't market the products we make. I got this trading spirit from the experiences I had related to buying and selling."

\section{5) The Motivational Factor}

The informant (R) stated that the motivation for his entrepreneurial interest was working hard and never giving up.

"There is motivation ..., so my motivation is to work hard and never get tired."

The informant $(\mathrm{Y})$ stated that with the motivation to be able to get a spirit of enthusiasm to develop his business.

"Of course I have motivation because with motivation we will get a spirit of trade spirit to develop the entrepreneurship."

The informant $(\mathrm{T})$ said that the motivation for entrepreneurship had freedom in determining the business he would run. 
Noviyan B.P., Supri W.U., \& Elana E.Y. / Analysis of Interest Factors for Entrepreneurship of Accounting

Education Students / JEE, Vol. 9, No. 2, September 2020, pp 85-100

"Yes I have motivation in entrepreneurship. Maybe for now I am only in the automotive sector, but in the past, my motivation was in the brick sector. And for now I also want to be in the catfish field."

The informant $(\mathrm{K})$ stated that his motivation to be interested in entrepreneurship was motivation to be the boss.

"If there is motivation in me because of that in entrepreneurship, we are like being the boss, you know ... so we better manage ourselves."

The informant $(\mathrm{P})$ stated that the motivation for interest in entrepreneurship is to become a successful entrepreneur.

"Because of my motivation, I want to be a successful entrepreneur like any other entrepreneur."

\section{Innovative Factors}

The informant (R) stated about his entrepreneurial innovation, namely about the industrial revolution 4.0.

"There are innovative thoughts, bro. This is already the 4.0 industrial revolution, right? So I will develop my father's business with even more sophisticated technology."

The informant $(\mathrm{Y})$ stated that innovating about the product or service to be offered.

"Of course, being an entrepreneur must have innovative thoughts because every product or service that will be offered to the customer will have a continuous innovation."

The informant $(\mathrm{T})$ stated that innovating by following what is the latest trend among consumers.

"Yes, of course we must have that in mind, bro, because we are among the buyers, we must have the latest trends."
The informant $(\mathrm{K})$ stated to innovate according to consumer needs related to the season.

"For innovative thinking, I prioritize the needs of buyers' interests according to current consumer needs. For example, now is the season for kites because of the strong winds, so I will prioritize selling kites in my business, bro, and what season will it be, so I will prioritize what consumers need."

The informant $(\mathrm{P})$ stated that he innovated by making updates to products that were acceptable to the general public.

"Yes, of course, I have innovative thoughts in my business by updating my products and being accepted by the general public."

\section{The Extrovert Factor}

The informant $(\mathrm{R})$ stated that he was an introvert but interested in entrepreneurship because there was support from his family and had a trading spirit, the informant $(\mathrm{R})$ was still interested in entrepreneurship.

"I am a quiet person or introvert so socializing is a bit difficult for me."

Informan $(\mathrm{Y})$ stated that he is an extrovert because he will be able to establish good social relationships between friends and other entrepreneurs.

"Yes, of course I have to have an extroverted personality because with that I can socialize with friends, between other entrepreneurs, can develop and also get information from various circles."

The informant (T) stated that he was an extrovert person on the grounds that if we are introverted, how to offer our products, so entrepreneurship must have an extroverted personality. 
"If that's definitely bro, that's already the initial capital in entrepreneurship. Because if we are quiet, how do we offer our products or our business to others?"

The informant $(\mathrm{K})$ stated that he is an extroverted person because in entrepreneurship, he must be smart in finding consumers and mingling with other people.

"In my opinion, yes! Because in trading, you have to be smart to find consumers, so be smart to mingle and continue to promote our wares."

The informant $(\mathrm{P})$ stated that he was an extrovert because in entrepreneurship we must be able to market our products to other people.

"Yes, I am an extroverted person, because in entrepreneurship we must be able to market our products to other people."

\section{Profit Factor}

The informant $(\mathrm{R})$ stated that getting benefits in entrepreneurship will have an impact on his future.

"Interested (feeling wealthy) because this is my future level of business ... yes, my descendants too."

The informant $(\mathrm{Y})$ stated that getting the benefits made him enthusiastic in innovating in his business.

"It is clear that I will definitely be interested in entrepreneurship because the more profit from entrepreneurship will automatically motivate myself to increasingly provide the latest innovations for my own entrepreneurship."

The informant $(\mathrm{T})$ states that the goal of entrepreneurship is to make a profit.

"If it's definitely interested, bro. Because the goal of entrepreneurship is to get that profit."
The informant $(\mathrm{K})$ stated that getting a profit became an interest in entrepreneurship.

"Yes, maybe one of them, bro, because that is the goal of establishing a business, you will definitely benefit from being one of the interests of entrepreneurship."

The informant $(\mathrm{P})$ stated that profit triggers enthusiasm in entrepreneurship.

"Of course, yes, because profit triggers my enthusiasm for entrepreneurship."

\section{Work Freedom Factor}

The informant (R) stated that the freedom to work by continuing the business of his parents.

"Because of entrepreneurship, we must be free to innovate and be free to work. So in entrepreneurship, there should be no limits."

The informant $(\mathrm{Y})$ stated that freedom of work means free to innovate in developing his business.

"Of course, with the freedom to work so that we can freely seek innovations and develop our own business because if we are free to seek innovation, we will develop a smooth business development."

The informant $(\mathrm{T})$ stated that freedom of work is freedom in regulating his working hours which no one else wants to control.

"Yes, bro, because if we do entrepreneurship, we are free in time, what time do we want to wake up, what time we want to go to bed, that's already free for us to do. So it's my choice if we wake up early we get more money, on the other hand, if we are up late, the money is definitely less."

The informant $(\mathrm{K})$ stated that freedom of work is an interest in entrepreneurship because of his desire not to be regulated. 
Noviyan B.P., Supri W.U., \& Elana E.Y. / Analysis of Interest Factors for Entrepreneurship of Accounting Education Students / JEE, Vol. 9, No. 2, September 2020, pp 85-100

'Yes, bro, I don't like being regulated, so if we set up our own business, we will be the boss, so we manage it ourselves."

The informant $(\mathrm{P})$ stated that with the freedom to work, he maximized his work to get a lot of profit.

"Of course, with the freedom to work we can work as much as possible to achieve a lot of benefits."

\section{Visionary Factors}

The informant $(\mathrm{R})$ stated that his vision of entrepreneurial interest is to make his business more quality and prosperous.

"Yes, my vision is to make my business more prosperous."

The informant $(\mathrm{Y})$ already has visionary thoughts because for him entrepreneurship is a valuable and important thing because it is to support his life later.

"Yes, I am now motivated to be a visionary, because entrepreneurship is a valuable and important thing for me to support the life to come. My personal aspiration is to have a business that will continue to grow and have innovation and produce positive results for society."

The informant $(\mathrm{T})$ from the beginning already had a vision and goals that would later be applied in his business.

"Surely, bro, if the vision and goals are there from the start, if you want to be successful, but the method is different or we've planned it."

The informant $(\mathrm{K})$ is a hard worker because from a young age he has been educated by his parents in terms of trading and wants to continue the vision of his parents.
"In my opinion, I am also a hard worker, God willing, bro, my lecture is also "in the gallery" to help my parents trade and God willing, I will continue the vision of my parents to continue this business."

Informant $(\mathrm{P})$ stated that he wanted to work in the future to realize his dream of becoming a successful ear mushroom entrepreneur.

"Yes, right now I want to work hard to achieve success in the entrepreneurial field that I will later establish."

\section{DISCUSSION}

Based on the results of research using data collection techniques in the form of interviews conducted by researchers related to the analysis of the factors of entrepreneurial interest. The students in terms of their very great interest in entrepreneurship are supported by several factors that are already owned by students of the Universitas PGRI Madiun Accounting Education Study Program. The number of choices or options in students interested in entrepreneurship makes entrepreneurship a priority in later choosing a career. Supported by the progress and conditions of the times that continue to develop and the phenomena that occur today, entrepreneurship is the right choice. The following is a discussion of the results of the interviews obtained by researchers:

\section{Based on Social Support Factors}

Social support is assistance that comes from people who have close social relationships with individuals who receive assistance (Nurhidayati and Utari, 2018). Where from the social support factors from students, family becomes 
important in the interest in student entrepreneurship because family support is the basis for students interested in entrepreneurship then support from friends is also important because the support from friends results in students being triggered in their desire to be entrepreneurial and for the support of the average student community. They do not have a strong bond with the community in that they are interested in entrepreneurship, this is in line with research from Primandaru (2017) where the social support factor becomes the belief in students to achieve success in entrepreneurship. Because with social support, students think that they are valuable and cared for. The social support factor is support from family friends and social where this support causes students to be motivated by this support to be interested in entrepreneurship.

The informant (R) has support from family and friends, but he is an introverted person, this does not become an obstacle for him in entrepreneurship because of the strong support from his family for entrepreneurship because his parents support him in entrepreneurship. Then the informant $(\mathrm{Y})$ has support from his family, friends and social environment. The informant $(\mathrm{T})$ also has strong support from family, friends and the environment, most of whom work in entrepreneurship. The informant $(\mathrm{K})$ has support from his family because he comes from a family that has run entrepreneurship but does not have support from friends or community, the social support he has gotten since he was a child because his parents taught him about entrepreneurship since he was a child. The informant $(\mathrm{P})$ has support from family and friends because many friends have already become entrepreneurs. So the conclusion from the social support factor is that the majority of informants want to become entrepreneurs because of the desire to inherit the business from their parents instead of starting a business from scratch.

\section{Based on the Mental Factor of Leadership}

The spirit of student leadership arises as a result of the maturation process, the spirit of student leadership related to entrepreneurship has been honed through the life process it lives in. Whether it's from the practice of life or events that are obtained from other people. The spirit of leadership can also arise due to the desire of students who want to be bosses, do not want to be regulated and the desire to have their own business where the business is managed by themselves, this is in line with research conducted by Praswati (2014) where leadership is a factor in student entrepreneurial interest. Leadership is an important asset to align its resources into a successful business (Gunawan and Cahayani, 2019). Without strong leadership, there is no big vision that can be built into a big business, and even develop the business.

The informant (R) has a leadership spirit because his motivation is to make his business better, but he is an introvert, this can have an effect later because a leader must be open and have good public speaking. The informant (Y) has a leadership spirit in that he is interested in entrepreneurship. The informant $(\mathrm{T})$ has a leadership spirit because he doesn't want to be enslaved by other people. This is in accordance with the question, namely:

"Because in myself I do not want to follow other people or be enslaved by these people".

Because the soul of a leader wants to manage something with the results of his own thoughts. The informant $(\mathrm{K})$ only has a little of 
Noviyan B.P., Supri W.U., \& Elana E.Y. / Analysis of Interest Factors for Entrepreneurship of Accounting Education Students / JEE, Vol. 9, No. 2, September 2020, pp 85-100

a leadership spirit, maybe because a woman is so her leadership level is still inferior to that of a man. Meanwhile, according to the informant (P) a man must have a leadership spirit. So the conclusion from the spirit of leadership is that the informants have a leadership spirit because of their desire to establish their own business. The spirit of leadership is a type of personality that arises as a result of a person's maturation process in his desire to lead a business.

\section{Based on Achievement Factors}

With the learning achievements that students have when they are in college, students have knowledge in entrepreneurship where students know how to market products and their management in entrepreneurship later. These factors can be developed through providing motivation to become entrepreneurs in the lecture process and through routine activities such as entrepreneurship training and entrepreneurship socialization (Retno, 2013). According to Amalia \& Hadi (2016) achievement is evidence of the results of success that have been obtained from the results of the interaction between several factors that affect both internally and externally. In Sari \& Rahayu's research (2019) there is a positive and significant influence between entrepreneurship education on the need for achievement.

The informant (R) argues that learning achievement has a relationship with interest in entrepreneurship, meaning that good learning achievement will support one's thinking so that the knowledge gained is useful and right on target. The informant $(\mathrm{Y})$ argues that learning achievement, good course grades and supported by entrepreneurial practice are related to entrepreneurial interest, meaning that entrepreneurship requires not only theory but direct practice in the field. This will be able to support or improve his skills in entrepreneurship. The informant $(\mathrm{T})$ stated that the interest in entrepreneurship is more related to the science of marketing management where it can be through social media, word of mouth and marketing mix, meaning that entrepreneurship must take advantage of the latest technology so that the process of entrepreneurship can be accessed easily both by himself and his consumers. The informant $(\mathrm{K})$ stated that the interest in entrepreneurship is more to the knowledge gained when taking entrepreneurship courses because this is an additional value in being interested in entrepreneurship, meaning that entrepreneurship can not only be done by only having talent but must be supported by standard knowledge about entrepreneurship so that entrepreneurs will be easily able to apply his knowledge of entrepreneurship. The achievement factor is the knowledge that is obtained when someone takes the world of education, this knowledge is related to the science of entrepreneurship.

\section{Based on the Trade Spirit Factor}

Based on the results of interviews with informants, students' trading spirit was obtained because of their own desire to trade and also obtained from the education taught by their parents. Because without a trading spirit, interest in entrepreneurship will not be able to arise because entrepreneurship is trading. This is in line with research from Ayuningtias and Ekawati (2015) where trade spirit enters personality where in this study personality has a significant effect on students' entrepreneurial interest.

The informant $(\mathrm{R})$ has a trading spirit, but he is an introvert. A trading spirit must be balanced with an extroverted personality because the skills to socialize and speak in public 
are needed for entrepreneurship. The informant $(\mathrm{Y})$ has a trading spirit in himself later as an entrepreneur. The informant $(\mathrm{T})$ has a trading spirit in entrepreneurship. The informant (K) has a trading spirit taught by his parents. The informant $(\mathrm{P})$ has a trading spirit in entrepreneurship. The trading spirit factor is a factor that is obtained from the willingness to do business and also from the education taught by his parents.

\section{Based on Motivational Factors}

Based on the results of interviews with informants, motivation becomes an impetus so that students continue to be motivated to realize their desires, namely entrepreneurship. All informants showed positive results on their interest in entrepreneurship. This is in line with research conducted by Ayuningtias and Ekawati (2015) that the entrepreneurial motivation factor significantly affects students' interest in entrepreneurship.

Motivation is an impulse from within the human soul that encourages to do things in achieving a desire/ideal (Hendrawan and Sirine, 2017). Entrepreneurial motivation is a driving force within itself that causes the creation of enthusiasm for the creation of an activity by seeing opportunities around it, acting boldly in taking risks, carrying out innovative activities and having a profit orientation (Majdi, 2012).

The informant $(\mathrm{R})$ stated that motivation is more to the urge to work hard and never get tired in realizing his dream of becoming a successful entrepreneur. The informant (Y) emphasizes the spirit of trade spirit to develop his entrepreneurship. The informant $(\mathrm{T})$ stated that the motivation for entrepreneurship is more about wanting to try all fields in entrepreneurship such as the automotive, brick and catfish business sectors. The informant $(\mathrm{K})$ stated that his entrepreneurial motivation was more on his desire to be the boss in managing his own business. The informant $(\mathrm{P})$ mentioned in the interview that his entrepreneurial motivation is being motivated to become a successful entrepreneur like other successful entrepreneurs. The motivational factor is the motivation which becomes the motivation for students to continue to be motivated in realizing their desire, namely entrepreneurship.

\section{Based on Innovative Factors}

Based on the results of interviews with informants, innovative thoughts are thoughts that can make updates in making a product that you want to sell to consumers. Innovative thinking can be done by following something that is trending according to the times. This is in line with research conducted by Praswati (2014), namely that the innovation factor has a positive influence on interest in entrepreneurship.

Innovative will produce goods, services, methods, processes and ways of solving problems that are new, useful and easy to understand (Mahanani \& Sari, 2018). Innovation cannot be separated from two criteria, namely integration and improvement (Saragih, 2017). The mix here is to create a new product but it is also useful according to its use, then improvement is to find other alternatives that are the best and easiest.

The informant (R) said that innovative thinking is more about technology in keeping up with the times. The informant $(\mathrm{Y})$ stated that innovating must have a continuous process regarding the products and services that you want to offer to consumers. The informant (T) emphasized that innovating must keep up with everything that is trending in the present or the 
Noviyan B.P., Supri W.U., \& Elana E.Y. / Analysis of Interest Factors for Entrepreneurship of Accounting Education Students / JEE, Vol. 9, No. 2, September 2020, pp 85-100

future. The informant $(\mathrm{K})$ stated consumer priority as a way to innovate about the product to be sold. The informant (P) stated that updating his product included his way of innovating. So innovating here must have a sustainable character because if it doesn't continue then the innovation will be useless. Innovative thinking is thinking that can make changes in making a product that you want to sell to consumers.

\section{Based on the Extrovert Factor}

Based on the results of interviews with informants, it is important to have extroverted personalities in entrepreneurial interest because extrovert personalities are the initial capital in an entrepreneurial person. Without an extroverted person in the entrepreneurial process, it is due to the difficulty of having social relationships with other people. This is in line with research conducted by Ayuningtias and Ekawati (2015) where extraverts are included in the personality factors that have a significant effect on students' interest in entrepreneurship.

The discussion regarding this extrovert factor was that the informant $(\mathrm{R})$ stated that he was an extroverted person. This has become my question why he is interested in entrepreneurship while he is an introvert. It turns out that the informant $(\mathrm{R})$ has strong support from his parents so that he is interested in entrepreneurship because his parents have first been involved in the world of entrepreneurship and now his business has developed well. The informant $(\mathrm{Y})$ stated that extrovert personality is because in establishing social relationships with friends and other entrepreneurs, extroverted personalities are needed. The extrovert person aims to make his business grow and also be able to get new information from various circles. The informant $(\mathrm{T})$ stated that a quiet person is a person who is not an entrepreneur in entrepreneurship. A person who can communicate well with other people or consumers is needed, therefore extroverted person is needed. The informant $(\mathrm{K})$ stated that intelligence in finding consumers and mingling with other people is a valuable asset in promoting his wares, this is needed by an extroverted person because having an extroverted person will be easy to do. The informant $(\mathrm{P})$ stated that in entrepreneurship, an extroverted person is needed because in entrepreneurship you must be able to market your products to other people in a neat way so that other people are interested in buying the goods. The extrovert person is the initial capital in being interested in entrepreneurship, the extrovert person must be able to socialize and communicate well with other people.

\section{Based on the Profit Factor}

All informants agreed that profit is an important reason why students set up a business. The profit generated is the profit obtained from all business activities carried out independently. The more profit the more advanced the business it runs. This is in line with research conducted by Saputri (2019) where profit is the main factor in students making a business. In Nurfitriya's research (2018) states that profits or profits will increase if an entrepreneur has a positive entrepreneurial attitude.

The informant $(\mathrm{R})$ stated that getting benefits in entrepreneurship will have an impact on his future. The informant $(\mathrm{Y})$ stated that getting the benefits made him enthusiastic in innovating in his business. The informant (T) states that the goal of entrepreneurship is to make a profit. The informant $(\mathrm{K})$ stated that getting a profit became an interest in entrepreneurship. Informant $(\mathrm{P})$ profit triggers enthusiasm in en- 
trepreneurship. Profits or profits cannot be obtained easily for that. In order to get a good profit, an entrepreneur must have good management. Good management can be done by doing budgeting, cost management and good financial reports.

\section{Based on the factor of freedom of work}

Based on interviews with informants, freedom to work is the desire of all informants because to work freely, the work they do will be managed by themselves without any rules from others. Free work also means free without restrictions in running a business. The freedom he wants at work is to get an income that is in accordance with the efforts of his business (Retno 2013). Entrepreneurship has the advantage of being able to have high freedom to organize your own business according to your wishes, besides that entrepreneurship also has the freedom to manage financial management time, and is free from superior rules because basically the entrepreneur is the boss of his own company (Pratiwi and Wardana, 2016)

The informant $(\mathrm{R})$ stated that the freedom to work by continuing the business of his parents. The informant $(\mathrm{Y})$ stated that freedom of work means free to innovate in developing his business. The informant (T) stated that freedom of work was freedom in regulating his working hours which no one else wanted to control. The informant $(\mathrm{K})$ stated that freedom of work has become an interest in entrepreneurship because of his desire not to be regulated. The informant $(\mathrm{P})$ stated that with the freedom to work, he maximized his work to get a lot of profit. Freedom to work is the desire of everyone because to work freely, the work that is carried out will be governed by themselves without any rules from others.

\section{Based on visionary factors}

Based on the results of interviews with informants regarding visionaries, the informants turned out to have visionary thoughts where they had planned the vision and goals that would be applied to the entrepreneurship later. A visionary person is someone who has plans to achieve his goals. The plan is balanced with an attitude of being willing to work hard and trying to make decisions with the right considerations (Retno, 2013).

The informant $(\mathrm{R})$ stated that his vision of entrepreneurial interest is to make his business more quality and prosperous. The informant (Y) already has visionary thoughts because for him entrepreneurship is a valuable and important thing because it is to support his life later. The informant $(\mathrm{T})$ from the beginning already had a vision and goals that would later be applied in his business. The informant $(\mathrm{K})$ is a hard worker because from a young age he has been educated by his parents in terms of trading and wants to continue the vision of his parents. The informant $(\mathrm{P})$ stated that he wanted to work in the future to realize his dream of becoming a successful ear mushroom entrepreneur. Visionary is a thought in which the vision and goals that will be applied to entrepreneurship have been planned. This visionary factor must be realized by students in entrepreneurship.

\section{CONCLUSION}

Based on the results of the above research, it can be concluded that the results of the 10 factors regarding entrepreneurial interest in students of the Universitas PGRI Madiun Accounting Education Study Program are as follows: 
Noviyan B.P., Supri W.U., \& Elana E.Y. / Analysis of Interest Factors for Entrepreneurship of Accounting Education Students / JEE, Vol. 9, No. 2, September 2020, pp 85-100

\section{Social Support Factors}

Of the five informants, the greatest support lies in family support. Because all parents of informants support their children to become entrepreneurs. For support from friends, only informants $(\mathrm{K})$ who did not have support from friends for informants R, Y, T, P had support from friends for entrepreneurship. For the community environment, the informants considered it less impactful because they did not have a community.

\section{The Spirit of Leadership}

Of the five informants, only the informant (K) has only a little leadership. Other informants have a leadership spirit. It is hoped that there will be training for all students. So that students have the ability to lead a business.

\section{Achievement Factor}

Of the five informants, only informants $(\mathrm{P})$ whose learning achievements regarding entrepreneurship are not good but are still interested in entrepreneurship. For other informants, learning achievement is an additional factor to be interested in entrepreneurship.

\section{Trade Spirit Factor}

Of the five informants, all of them have a trading spirit to be interested in entrepreneurship, which is obtained in different ways.

\section{The Motivational Factor}

Of the five informants, they have different entrepreneurial motivation but have the same goal, namely to become a successful entrepreneur.

\section{Innovative Factors}

Of the five informants, innovative thinking has become an interest in student entrepreneurship because innovative thinking supports a business.

\section{The Extrovert Factor}

Of the five informants, only the informant (R) did not have an extrovert personality but was interested in entrepreneurship because of the strong support from his family. For the four informants, namely informants $\mathrm{Y}, \mathrm{T}, \mathrm{K}, \mathrm{P}$, each of them has an extroverted personality, therefore a public speaking training is held which will be able to hone students' skills in public speaking in terms of marketing their products.

\section{Profit Factor}

Of the five informants, the profit factor is the goal of entrepreneurial interest.

\section{Work Freedom Factor}

Of the five informants, freedom to work has become a separate dream in relation to working in the entrepreneurial field.

\section{Visionary Factors}

Of the five informants, all of them already have a visionary spirit in that they are interested in entrepreneurship.

The limitation of this research is that there are informants who do not want to mention or provide information to researchers about the value of entrepreneurship courses they receive. Regarding this matter, the informants felt sensitive to mention this value.

Suggestions for the Accounting Education Study Program are to further develop learning 
in entrepreneurship courses, for example the additional hours of entrepreneurship courses and entrepreneurship courses are not only taken in 1 semester so that students really understand the theory and practice of entrepreneurship.

In addition, the researcher suggests holding basic leadership training on entrepreneurship to hone the spirit of leadership for all students at the Universitas PGRI Madiun to all students in order to create competent new entrepreneurs. This is because so far only students who participate in organizations receive basic leadership training. Public speaking training is also important to market a quality product and has a high selling value to hone students' skills in public speaking.

In future studies that wish to research this type of research, it is hoped that the informants in this study will be contacted. So that this researcher can find out the realization of the informant's recognition related to dreams and reality in entrepreneurship.

\section{REFERENCES}

Adnyana, I. \& Purnami, N. (2016). Pengaruh Pendidikan Kewirausahaan, Self Efficacy, dan Locus of Control pada Niat Berwirausaha. E-Jurnal Manajemen Universitas Udayana, 5(2), 1160-1188.

Amalia, H. N. \& Hadi, S. (2016). Pengaruh Prestasi dan Lingkungan Terhadap Minat Berwirausaha Siswa Jurusan Pemasaran. Economic Education Analysis Journal, 5(3), 761-773.

Anonymous. (2018). Indonesia Butuh 4 Juta Wirausaha Baru untuk Menjadi Negara Baru. Retrieved June 27, 2020, from https:/ /www.kemenperin.go.id.

Ayuningtias, H. A. \& Ekawati, S. (2017). FaktorFaktor yang Memengaruhi Minat Berwira- usaha pada Mahasiswa Fakultas Ekonomi Universitas Tarumanagara. Jurnal Ekonomi, 20(1), 49-71.

BPS. (2018). Proyeksi Jumlah Penduduk Indonesia Tahun 2020. Retrieved June 28, 2020, from http://www.bps.go.id.

BPS. (2020). Keadaan Ketenagakerjaan Indonesia. Retrieved June 27, 2020, from https:/ /www.bps.go.id.

Franita, R. (2016). Analisa Pengangguran Di Indonesia. Jurnal Ilmu Pengetahuan Sosial, 1 (Desember 2016), 88-93.

Gunawan, A. S. \& Cahayani, A. (2018). Tinjauan Peran Kepemimpinan Wirausaha dengan Fokus Eksternal pada Wirausahawan Pelaku Bisnis Kuliner di Jakarta. Conference on Management and Behavioral Studies 2018, 39-48.

Hendrawan, J. S. \& Sirine, H. (2017). Pengaruh Sikap Mandiri, Motivasi, Pengetahuan Kewirausahaan Terhadap Minat Berwirausaha (Studi Kasus pada Mahasiswa FEB UKSW Konsentrasi Kewirausahaan). Asian Journal of Innovation and Entrepreneurship, 02(03), 291-314.

Mahanani, E., \& Sari, B. (2018). Faktor-Faktor yang Memengaruhi Minat Berwirausaha Mahasiswa Fakultas Ekonomi Universitas Persada Indonesia. Ikraith-Humaniora, 2(2), 31-40.

Majdi, M, Z. (2012). Pengaruh Pembelajaran Kewirausahaan, Internalisasi Nilai Kewirausahaan di Keluarga dan Motivasi Minat Kewirausahaan. Jurnal Pendidikan, 7(2), $1-25$.

Nurfitriya, M. (2018). Sikap Kewirausahaan dan Pengaruhnya Terhadap Perkembangan Usaha Kerajinan Batik di Tasikmalaya. Jurnal Pendidikan Ekonomi, 11(1), 1-8.

Nurhidayati, N. \& Utari, D. T. (2018). Model Intensi Kewirausahaan dengan Pertim- 
Noviyan B.P., Supri W.U., \& Elana E.Y. / Analysis of Interest Factors for Entrepreneurship of Accounting

Education Students / JEE, Vol. 9, No. 2, September 2020, pp 85-100

bangan Pasar Kerja, Dukungan Sosial, dan Sel Efficacy Terhadap Pengambilan Keputusan Karier. Jurnal Ekonomi dan Bisnis, 19(2), 111-120.

Praswati, A. N. (2014). Analisis Faktor-Faktor yang Memengaruhi Minat Wirausaha di Kalangan Mahasiswa Studi Kasus: Fakultas Ekonomi dan Bisnis Universitas Muhammadiyah Surakarta. Seminar Nasional dan Call for Paper (Sancall) 2014, 134-142.

Pratiwi, Y. \& Wardana, I. M. (2016). Pengaruh Faktor Internal dan Eksternal Terhadap Minat Berwirausaha Mahasiswa Fakultas Ekonomi dan Bisnis Universitas Udayana. E-Jurnal Manajemen, 5(8), 5215-5242.

Primandaru, N. (2017). Analisis Faktor-Faktor yang Berpengaruh pada Minat Berwirausaha Mahasiswa. Jurnal Economia, 13(1), 68-78.

Retno, S. \& Sumaryati, S. (2013). Faktor-Faktor yang Memengaruhi Minat Berwirausaha pada Mahasiswa Program Studi Pendidikan
Ekonomi FKIP UNS. Jupe UNS, 2(1), 95106.

Saputri, N. A. (2019). Analisis Faktor-Faktor yang Memengaruhi Minat Mahasiswa Berwirausaha. Jurnal Inovasi Ekonomi, 4(01), 13-18.

Saragih, R. (2017). Membangun Usaha Kreatif, Inovatif dan Bermanfaat Melalui Penerapan Kewirausahaan. Jurnal Kewirausahaan, 3(Desember), 26-34.

Sari, B. \& Rahayu, M. (2019). Pengaruh Pendidikan Kewirausahaan, Kebutuhan akan Prestasi dan Efikasi Diri Terhadap Intensi Berwirausaha Siswa SMA Muhammadiyah I Jakarta, Ikraith-Ekonomika, 2(1), 2231.

Sugiyono. (2016). Metode Penelitian Kualitatif, Kuantitatif, dan RひDD. Bandung: Alfabeta. Suyono, N. A. (2019). Faktor-Faktor yang Memengaruhi Minat Berwirausaha. Jurnal Ekonomi dan Teknik Informatika, 7(1), 10-21. 